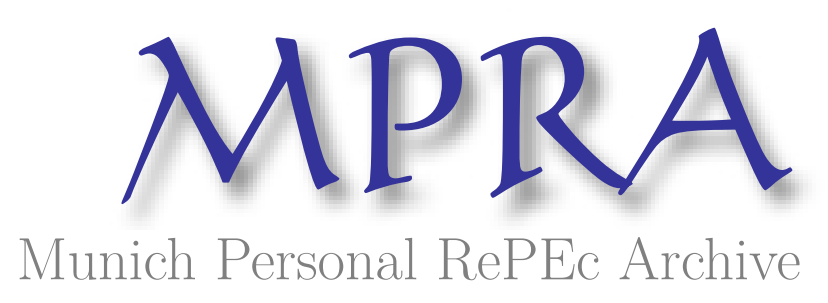

\title{
Intermediate Goods and Exchange Rate Disconnect
}

\author{
Craighead, William \\ Colorado College
}

1 December 2017

Online at https://mpra.ub.uni-muenchen.de/83075/

MPRA Paper No. 83075, posted 08 Dec 2017 06:11 UTC 


\title{
Intermediate Goods and Exchange Rate Disconnect
}

\author{
William D. Craighead* \\ Colorado College
}

November 2017

\begin{abstract}
This paper introduces intermediate goods trade into a two-country real business cycle model and examines its implications for real exchange rate behavior. Intermediate goods trade is shown to reduce "exchange rate disconnect" by increasing the volatility of the real exchange rate relative to output and weakening the link between the real exchange rate and output. Intermediate goods trade also raises international output correlations and reduces the correlation between the trade balance and output.

JEL: F41, F31
\end{abstract}

*Assistant Professor, Economics and Business Department, Colorado College, 14 E. Cache LaPoudre St., Colorado Springs CO 80903 USA.

E-mail: bcraighead@coloradocollege.edu. Tel.: +1 719-389-6414.

Acknowledgements: I am grateful to conference participants at the 2016 Southern Economic Association Meeting, the 2017 Eastern Economic Association Meeting, the 2017 Georgetown Center for Economic Research Biennial Conference and the 2017 Workshop in Macroeconomic Research at Liberal Arts Colleges as well as Lena Ogrokhina, Pao-Lin Tien and Liang Ding for helpful comments. Any errors are my own. 


\section{Introduction}

One of the longstanding puzzles in international macroeconomics is what Obstfeld and Rogoff (2001) describe as the "remarkably weak short-term feedback

links between the exchange rate and the rest of the economy." The high volatility of real exchange rates relative to GDP is one significant aspect of this "exchange rate disconnect" puzzle.

This paper investigates whether trade in intermediate goods can help explain this puzzle. The production structure of a two-country real business cycle model is extended to incorporate intermediate goods trade. Doing so raises the volatility of the real exchange rate relative to output and weakens the link between the real exchange rate and output. Intermediate goods trade also raises international output correlations and reduces the correlation between output and net exports.

This paper focuses on a real aspect of economic structure in accounting for exchange rate disconnect. Other real factors that have been studied in relation to this puzzle include distribution costs (Burstein et al. (2003), Corsetti et al. (2008)) and costs of reallocating resources between traded and non-traded goods sectors (Craighead, 2008). Although money and nominal rigidities are absent from this paper, the hypothesis may be considered complementary to alternative explanations of exchange rate disconnect which focus on price stickiness and exchange rate pass through, such as Devereux and Engel (2002).

A number of papers have quantified the growth of intermediate goods trade. The pioneering work by Hummels et al. (2001) measured "vertical specialization" as the share of imported intermediate inputs in exports. Daudin et al. (2011), Koopman et al. (2014) and Johnson and Noguera (2012, 2016) calculate the ratio of domestic value added to gross exports - unlike Hummels et al. (2001), they account for intermediate exports that return to their country of 
origin incorporated into final goods. The findings of these papers are similar. For 2004, Daudin et al. (2011) report a ratio of value added to exports of 0.73 , Koopman et al. (2014) estimate the ratio as 0.74 for the same year. Johnson and Noguera (2016) report this ratio fell from 0.87 in 1970 to 0.76 in 2008, before rebounding to 0.79 in 2009. Los, Timmer and deVries (2015) perform a similar exercise, but focus only on manufacturing industries.

This paper adds to a body of literature incorporating intermediate goods trade into international business cycle models. In a two-country model where each country's output is also used as an input in the other country, Canova and Dellas (1993) show that intermediate goods trade raises international output correlations. Ambler et al. (2002) incorporate intermediate goods into a two-country RBC model and find that their model is better able to match international output correlations, but they attribute this to the presence of multiple sectors and investment adjustment costs rather than intermediate goods trade. Several of these papers have examined whether trade in intermediate goods trade can help match the empirical observation that business cycle fluctuations are more correlated among countries with greater trade. Kose and Yi (2001) find that vertical specialization does little to improve the ability of a two-country RBC model to match output correlations. In a model with multi-stage production and firm heterogeneity, Arkolakis and Ramanarayanan (2009), find that intermediate goods trade alone does little to increase predicted comovement, but extending the model to include imperfect competition is beneficial in this regard. Johnson (2014) builds a multicountry model with intermediate goods trade and finds that its ability to match international comovements is limited. However, Burstein et al. (2008) find that production sharing trade through vertically integrated multinationals with foreign affiliates can help explain business cycle synchronization. Relatedly, Boileau (2002) showed that integrating 
international trade in capital equipment and investment-sector shocks into a two country RBC model also generates positive output comovement.

Intermediate goods trade has also been considered in sticky price models. In a two-country model with multistage production, Huang and Liu (2007) find that intermediate goods trade leads to a larger and more persistent response of the real exchange rate to a monetary shock. They find that intermediate goods trade raises international output correlation, but only modestly increases the volatility of the real exchange rate. Lombardo and Ravenna (2014) investigate optimal monetary policy for a small open economy with intermediate goods trade.

\section{Background}

Table 1 reports the standard deviations of the real effective exchange rate, the real exchange rate vs. the US, the trade balance as a share of GDP and real GDP for the G-7 and euro area as a whole ${ }^{1}$. All variables are quarterly and are in percent changes, except the trade balance relative to GDP, which is expressed as a percentage point change.

Exchange rate disconnect is evident in the high volatility of the real exchange rate compared to output. Both the REER and RER vs. the US are considerably more volatile than the trade balance or real GDP for all of the countries and the euro area.

Weak correlations between the real exchange rate and output and trade balances are another aspect of exchange rate disconnect. Table 2 shows the correlations between real GDP growth and changes in the REER, RER vs. US for the G-7 and euro area. The absolute correlations are all 0.25 or less.

\footnotetext{
${ }^{1}$ The real effective exchange rate is the BIS narrow measure; all other data are from the OECD. For Canada, France, the UK and US, the sample is 1981Q1-2014Q4; for Germany, 1991Q1-2014Q4; Japan, 1994Q1-2014Q4; Italy 1996Q1-2014Q4; and the euro area, 1995Q12013Q3. Real exchange rates vs. the US are constructed using GDP deflators.
} 
Correlations between the changes in the NX/GDP ratio and changes in the REER and RER vs. US are reported in Table 3. The correlations between changes in the real exchange rate measures and the trade balance are also very low, and changes in the trade balance appear to have little or no consistent relationship to GDP growth.

Although it is not the main focus, this paper also has implications for international output comovements. Table 4 reports the correlations of real GDP growth among the G-7 countries, which illustrate the well-known tendency of cyclical correlation among national economies. The correlations of GDP growth with the euro area as a whole are 0.67 for Canada, 0.48 for Japan, 0.74 for the UK and 0.58 for the US.

\section{Model}

The model is a two-country RBC model of the type pioneered by Backus et al. (1992). The countries, labeled $A$ and $B$, are symmetric. To minimize redundancy, the exposition below will focus on country $A$.

\subsection{Technology}

Each country has two sectors, an intermediate goods sector, denoted using a superscript $M$, and a final goods sector, denoted with a superscript $F$. Country A's intermediate sector uses a Cobb-Douglas combination of factors to produce an input for final goods production in both countries:

$$
M_{t}^{A, A}+M_{t}^{A, B}=Z_{t}^{M, A}\left(K_{t}^{M, A}\right)^{\alpha}\left(N_{t}^{M, A}\right)^{1-\alpha}
$$

where $M^{A, A}$ and $M^{A, B}$ denote intermediate goods produced in country $A$ as inputs for final goods in countries $A$ and $B$, respectively, $K$ and $N$ are capital 
and labor, and $Z$ is a technology shifter.

Final goods are produced using intermediate goods as well as factor inputs. Intermediate goods are combined according to a constant elasticity of substitution aggregator,

$$
X_{t}^{A}=\left[\omega^{\frac{1}{\psi}}\left(M_{t}^{A, A}\right)^{\frac{\psi-1}{\psi}}+(1-\omega)^{\frac{1}{\psi}}\left(M_{t}^{B, A}\right)^{\frac{\psi-1}{\psi}}\right]^{\frac{\psi}{\psi-1}}
$$

where $M^{B, A}$ represents intermediate goods produced in country $B$ that are used in $A, \psi$ is the elasticity of substitution between domestic and imported intermediates and $\omega$ is the weight on domestic intermediates. Capital and labor are combined according to a Cobb-Douglas function,

$$
V^{A}=Z_{t}^{F, A}\left(K_{t}^{F, A}\right)^{\alpha}\left(N_{t}^{F, A}\right)^{1-\alpha}
$$

and the final goods are produced by combining the factor and intermediate goods inputs,

$$
Y_{t}^{F, A}=\left[\sigma^{\frac{1}{\mu}}\left(V_{t}^{A}\right)^{\frac{\mu-1}{\mu}}+(1-\sigma)^{\frac{1}{\mu}}\left(X_{t}^{A}\right)^{\frac{\mu-1}{\mu}}\right]^{\frac{\mu}{\mu-1}}
$$

where $\sigma$ is the weight on factor inputs and $\mu$ is the elasticity of substitution between factors and intermediate goods inputs.

The final good is used for consumption in both countries and investment in both domestic sectors,

$$
Y_{t}^{F, A}=C_{t}^{A, A}+C_{t}^{A, B}+I_{t}^{A, A}+I_{t}^{A, B}
$$

where $C_{t}^{A, A}$ and $C_{t}^{A, B}$ are consumption of country A's final good in country A and B, respectively and $I^{A, A}$ and $I^{A, B}$ represent the use of country A's final good for investment in country A and B. 
The investment good is an aggregate of domestic and imported final goods,

$$
I_{t}^{A}=\left[\phi^{\frac{1}{\eta}}\left(I_{t}^{A, A}\right)^{\frac{\eta-1}{\eta}}+(1-\phi)^{\frac{1}{\eta}}\left(I_{t}^{B, A}\right)^{\frac{\eta-1}{\eta}}\right]^{\frac{\eta}{\eta-1}}
$$

where $\phi$ is the weight on domestic goods and $\eta$ is the elasticity of substitution between domestic and imported goods.

The investment good is allocated to the two sectoral capital stocks,

$$
I_{t}^{A}=I_{t}^{F, A}+I_{t}^{M, A}
$$

Capital is sector-specific and accumulates according to

$$
K_{t+1}^{j, A}=(1-\delta) K_{t}^{j, A}-\frac{\nu}{2}\left(K_{t+1}^{j, A}-K_{t}^{j, A}\right)^{2}+I_{t}^{j, A} \quad j=F, M
$$

where $\delta$ is the depreciation rate and $\nu$ governs the degree of capital adjustment costs.

\subsection{Preferences}

Representative households in each country are of unit measure receive and utility from consumption and disutility from labor. The lifetime utility function of the country A household is given by

$$
U^{A}=\mathrm{E} \sum_{t=0}^{\infty} \beta^{t} D_{t}^{A}\left[\frac{\left(C_{t}^{A}\right)^{1-\gamma}}{1-\gamma}-\chi s^{A} \frac{\left(\widetilde{N}_{t}^{F, A}\right)^{1+\theta}}{1+\theta}-\chi\left(1-s^{A}\right) \frac{\left(\widetilde{N}_{t}^{M, A}\right)^{1+\theta}}{1+\theta}\right]
$$

where $D_{t}^{A}$ is an intertemporal preference shifter, $s^{A}$ is the fraction of the household working in the final goods sector and $\widetilde{N}_{t}^{F, A}$ and $\widetilde{N}_{t}^{M, A}$ represent labor per worker in each sector. Total labor in the final goods sector is $N_{t}^{F, A}=s^{A} \widetilde{N}_{t}^{F, A}$ and it is $N_{t}^{M, A}=\left(1-s^{A}\right) \widetilde{N}_{t}^{M, A}$ in intermediate goods production. The share 
of the household in the final goods sector, $s^{A}$, is set so the wages and labor per worker are equalized across the two sectors in the steady state. The household consumption bundle, $C^{A}$, is comprised of domestically produced final goods, $C^{A, A}$, and imports of final goods produced in country $\mathrm{B}, C^{B, A}$, which are aggregated in the same way as the investment good,

$$
C_{t}^{A}=\left[\phi^{\frac{1}{\eta}}\left(C_{t}^{A, A}\right)^{\frac{\eta-1}{\eta}}+(1-\phi)^{\frac{1}{\eta}}\left(C_{t}^{B, A}\right)^{\frac{\eta-1}{\eta}}\right]^{\frac{\eta}{\eta-1}}
$$

The weighting parameter $\phi$ can be thought of as governing the degree of "home bias."

\subsection{Solution}

The model is solved as a social planner's problem, where the planner maximizes the sum of the utility functions of the two representative households. The resulting system of equations is log-linearized and then solved using Dynare (Adjemian et al. 2011). Because the model is solved as a planner's problem, relative prices - including the real exchange rate - are inferred from lagrange multipliers.

Productivity in each sector is assumed to be stochastic, with deviations from the steady state following an $\mathrm{AR}(1)$ process:

$$
\widehat{Z}_{t}^{j, A}=\rho_{Z} \widehat{Z}_{t-1}^{j, A}+\varepsilon_{Z, t}^{j, A} \quad \varepsilon_{Z, t}^{j, A} \sim N\left(0, \sigma_{Z, \varepsilon}^{2}\right) \quad j=F, M
$$

where $\widehat{Z}$ denotes the percentage deviation of productivity from its steady-state value of 1 .

The changes in the intertemporal preference shifter also follow an $\operatorname{AR}(1)$ process:

$$
\widehat{D}_{t}^{A}=\rho_{D} \widehat{D}_{t-1}^{A}+\varepsilon_{D, t} \varepsilon_{D, t}^{A} \sim N\left(0, \sigma_{D, \varepsilon}^{2}\right)
$$


Parameter values are listed in Table 5. Where possible, they are set at common values in the literature. Values for the discount factor, risk aversion and the capital share are standard. The weight on labor, $\chi$, is set so that $25 \%$ of time is spent working. The Frisch elasticity of labor supply is somewhat controversial, but the value chosen here is a common one in the RBC literature (for a recent discussion, see Peterman (2016)).

The weight on factor inputs, $\sigma$, is consistent with the materials share of 0.54 in US manufacturing in 1987 reported by Oberfeld and Raval (2014) and the unweighted average value of the cost share of intermediate inputs reported by sector in Atalay (2017) of 0.55 . The elasticity between factor inputs and intermediate goods, $\mu$, is based on the elasticity between materials and factor inputs for US manufacturing 1997 of 0.63 estimated by Oberfeld and Raval (2014). Atalay (2017, online appendix) finds a similar value when employing the same methodology, but arrives at somewhat higher estimates using industrylevel rather than plant-level data. Rotemberg and Woodford (1997) estimated of a similar value of 0.69 .

The value of the elasticity of substitution between domestic and foreign consumption, $\eta$, follows Backus, Kehoe and Kydland (1994). Estimates of this parameter vary substantially between international finance and trade studies and this value is in line with estimates at the macro level (for a discussion see Yilmazkuday (2017)). The literature provides little guidance on the elasticity of substitution between domestic and imported intermediates - Atalay (2017) finds elasticities near zero for inputs from differing sectors. Inputs from different countries are likely more substitutable; an elasticity of 0.75 is assumed, which is less than one, but greater than the elasticity between intermediate goods and factor inputs.

The chosen value for the autocorrelation of the preference shock is consistent 
with results of estimated models such as Garín, Lester and Sims (2016). The standard deviation of the productivity shocks is set at $1 \%$ for ease of interpretation; this is slightly higher than typically assumed in RBC studies. Capital adjustment costs are a standard feature of open-economy models. In singlesector models, they are necessary to prevent excessive volatility of investment. That is not the case in a multi-sector model such as this one, but a modest adjustment cost prevents sudden large movements of capital from one sector to the other.

The effect of intermediate goods trade is examined by varying $\omega$, the weight on domestic intermediate goods. Increasing $\omega$ reduces the share of domestic value added in a country's exports - i.e., the importance of imported intermediates that are re-exported in final goods declines as $\omega$ increases. With $\omega=0.95$, domestic value added is $97.4 \%$ of exports, decreasing to $82.2 \%$ when $\omega$ increases to 0.5 and $74.4 \%$ at $\omega=0.05$. The later values are in the range of estimates of the value added-export ratio found in the literature discussed above.

\section{Results}

Selected moments generated by the model are reported in Table 6, where $Q$ is used to denote the model-generated real exchange rate, $Y$ is GDP and $N X$ is net exports. Output volatility decreases as intermediate goods trade rises ( $\omega$ falls) because production sharing due to intermediate goods trade implies that each country's domestic output has a foreign component which is not directly affected by a domestic productivity shock. Intermediate goods trade also reduces the correlation between output and the trade balance, as increasing output requires additional imports of intermediate goods.

International output correlations increase with intermediate goods trade because a positive shock in one country's intermediate goods sector creates more 
supply of intermediates to the other, and a shock in the final goods sector in one country raises demand for intermediates from the other. These results are more supportive of the view that intermediate goods trade can help explain international output correlations than those of Ambler et al. (2002) and Arkolakis and Ramanarayanan (2009) mentioned earlier. The divergence in results are likely due to varying assumptions. In the case of Ambler et al. (2002), the production structure is somewhat different - in that paper, each country has two sectors that produce intermediate goods, rather than an intermediate and final goods sector. Unlike this paper, Arkolakis and Ramanarayanan (2009) assume no asset trade between countries, which means that balanced trade holds at all times.

In international RBC models output fluctuations are generated by productivity shocks, which cause output and the real exchange rate to move in the opposite direction. This model includes a preference shock, but the productivity fluctuations are the primary driver of economic fluctuations. Intermediate goods trade reduces the magnitude of the negative real exchange rate - output correlation, moving the model-generated results closer to the data.

These results also indicate that intermediate goods trade can help account for one important aspect of "exchange rate disconnect" - the high volatility of the real exchange rate relative to output. With $\omega=0.95$, the standard deviation of the real exchange rate is lower than that of output, rising to 1.25 times that of output when $\omega=0.5$ and 1.42 times when $\omega=0.05$.

Figures 1 and 2 report impulse response functions for the real exchange rate for positive technology shocks in each country A sector under different values of $\omega$. For the final goods sector productivity shock, the initial effect is increasing as $\omega$ decreases, while for the intermediate goods sector productivity shock, the effect increases when $\omega$ falls from 0.95 to 0.5 , but the initial effects are similar 
for the $\omega=0.5$ and $\omega=0.05$ cases.

To understand how $\omega$ interacts with the real exchange rate, it is useful to to decompose it. The real exchange rate, $Q$, is measured as the ratio of country A's GDP deflator, $P^{A}$, to country B's, $P^{B}$. To find country A's deflator, first note that the expenditure approach to GDP implies:

$$
\begin{aligned}
Y^{A} & =C^{A}+I^{A}+N X^{A} \\
& =C^{A, A}+C^{B, A}+I^{A, A}+I^{B, A}+C^{A, B}+I^{A, B}+M^{A, B}-\left(C^{B, A}+I^{B, A}+M^{B, A}\right) \\
& =C^{A, A}+C^{A, B}+I^{A, A}+I^{A, B}+M^{A, B}-M^{B, A} \\
& =Y^{F, A}+M^{A, B}-M^{B, A}
\end{aligned}
$$

Using carets to denote percent deviations from the steady state, the change in the price level is a weighted average of the changes in the prices of domestic final goods, domestic intermediates, and foreign intermediates:

$$
\widehat{P}^{A}=\Psi_{1} \widehat{P}^{F, A}+\Psi_{2} \widehat{P}^{M, A}-\Psi_{3} \widehat{P}^{M, B}
$$

where $\Psi_{1}, \Psi_{2}$ and $\Psi_{3}$ are weights and the lagrange multipliers on the resource constraints for country A's final and intermediate goods sectors are used for $P^{F, A}$ and $P^{M, A}$, respectively. In a symmetric steady state where all the the technology terms (i.e, the $Z$ 's) are normalized at one, the weights are $\Psi_{1}=1$ and $\Psi_{2}=\Psi_{3}=(1-\omega)(1-\sigma)$. The percent deviation of country A's price level from the steady state is thus:

$$
\widehat{P}^{A}=\widehat{P}^{F, A}+(1-\omega)(1-\sigma) \widehat{P}^{M, A}-(1-\omega)(1-\sigma) \widehat{P}^{M, B}
$$


Similarly,

$$
\widehat{P}^{B}=\widehat{P}^{F, B}+(1-\omega)(1-\sigma) \widehat{P}^{M, B}-(1-\omega)(1-\sigma) \widehat{P}^{M, A}
$$

Hence,

$$
\widehat{Q}=\widehat{P}^{A}-\widehat{P}^{B}=\widehat{P}^{F, A}-\widehat{P}^{F, B}+2(1-\omega)(1-\sigma)\left(\widehat{P}^{M, A}-\widehat{P}^{M, B}\right)
$$

That is, real exchange rate movements depend on changes in relative final goods prices, $\widehat{P}^{F, A}-\widehat{P}^{F, B}$ and relative intermediate goods prices, $\widehat{P}^{M, A}-\widehat{P}^{M, B}$. Note that intermediate goods prices do not directly enter if intermediate goods are not used in final output $(\sigma=1)$ or if there is no trade in intermediate goods ( $\omega=$ 1). As intermediate goods trade rises, the direct impact of changes in relative intermediate goods prices increases. Of course, shocks to the intermediate goods sector may also have an indirect effect through the price of final goods.

In the case of the shock to final goods sector productivity, $\widehat{Z}^{F, A}$, the depreciation of the real exchange rate is largely driven by a decrease in the price of the country A final good compared to the country B final good, shown in Fig. 3. When the share of imported intermediates increases from $5 \%$ to $50 \%$, the decline in the relative price of the country A final good is larger - its supply expands more because country A can increase output by importing more intermediates from country B. The shift in both countries' intermediate goods production in favor of inputs for final goods produced in country A allows country A's final output to expand more, but causes country B's final output to fall. As country A's final output expands more while country B's shrinks, the relative final goods price movement, $\widehat{P}^{F, A}-\widehat{P}^{F, B}$, is larger. When the share of imported intermediates is $95 \%$, the supply of intermediates is similar to the case where the share is $5 \%$ and any additional intermediates used in country A's final out- 
put come largely from a single country, though in this case it is country B. The change in final goods output is the same under $\omega=0.95$ and $\omega=0.05$; final output in country A expands more with $\omega=0.5$ because the supply of inputs is more responsive in this case, being drawn equally from both countries. The increase in the real exchange rate movement in the $\omega=0.05$ case is because of the $\widehat{P}^{M, A}-\widehat{P}^{M, B}$ term, shown in Fig. 4. With $\omega=0.05$, the coefficient on it is larger, and, in this case, $P^{M, B}$ is increasing substantially as country A output rises due to the shock and therefore more intermediates from country B are needed. Since $\widehat{P}^{M, B}$ enters $\widehat{Q}$ negatively, this amplifies the decline in $Q$.

When productivity increases in the home intermediate sector, the largest decrease in prices that of the home intermediate good, causing a large decrease in relative intermediate goods prices shown in Fig. 5. With $\omega=0.95$, the coefficient on the $\widehat{P}^{M, A}-\widehat{P}^{M, B}$ term is small, but the increase in output of country A intermediates also causes country A's final goods production to rise, decreasing $\widehat{P}^{F, A}-\widehat{P}^{F, B}$, as shown in Fig. 6. With $\omega=0.5$, the effect on final goods production is symmetric, so $\widehat{P}^{F, A}-\widehat{P}^{F, B}=0$, but a decline in $Q$ results from the decrease in $P^{M, A}$. As $\omega$ decreases from 0.5 to 0.05 , the effect of the increased coefficent on the $\widehat{P}^{M, A}-\widehat{P}^{M, B}$ term is partly offset by a decrease in the price of country B final output due to an expansion in the supply of the supply of the intermediates used to produce it. This causes the relative final goods price term, $\widehat{P}^{F, A}-\widehat{P}^{F, B}$, to increase since the price of the country B final good enters negatively.

The shock to $D^{A}$, which increases the relative weight on the current utility of country A's representative household, causes the real exchange rate to increase. The magnitude of the increase is greater as intermediate goods trade rises, as shown in Fig. 7. Since $\phi=0.5$, the shock does not affect relative demand, so the results are not attributable to home bias. In this case, the preference shock 
acts similarly to a negative supply shock as it increases the relative weight on country A's leisure. This reduces the supply of intermediate and final goods from country A.

Responses of relative final goods prices and intermediate goods prices to the $D^{A}$ shock are given in Figs. 8 and 9. With $\omega=0.95$, the reduction in labor supply reduces the supply of country A's intermediate and final goods, raising their relative prices. When $\omega=0.5$, the effect of the reduced supply of country A's intermediate goods is spread across both countries' final goods sectors, so the change in relative final goods prices is smaller. The change in relative intermediate goods prices is slightly larger with $\omega=0.5$, as country A's intermediates are equally required for final goods production in both countries. With $\omega=0.95$, the reduction in the supply of country A's intermediates on country B final goods production is large enough that the price of country B final goods increases more than country A final goods, resulting in a slight decrease in the relative final goods price term. Although the magnitude of the change in relative final goods prices decreases as $\omega$ rises, the increased weight on relative intermediate goods prices leads to a greater overall increase in $Q$.

Although insight is gained by examining sectoral productivity shocks in isolation and considering a preference shock as well, the shock process used above deviates from that of conventional international RBC models. To consider the effect of intermediate goods trade under more standard assumptions about shocks, the sectoral productivity levels are set to be the same within each country, i.e., $Z^{F, A}=Z^{M, A}=Z^{A}$ and $Z^{F, B}=Z^{M, B}=Z^{B}$ and the demand shocks are eliminated. As with the sectoral shocks above, in this case each country's productivity follows an $\operatorname{AR}(1)$ process with $\rho=0.9$ and standard deviation of 0.01 and they are independent of each other. Moments generated by the model under this assumption ("National Productivity Shocks") are reported 
in table 7 .

As in the case with the sectoral-level shocks, under national productivity shocks, intermediate goods trade reduces increases real exchange rate volatility, both absolutely and relative to output volatility. The increase in the crosscountry output growth correlation and the reduced correlation between the trade balance and output, and reduced negative correlation between the real exchange rate and output are also similar in this case.

Fig. 10 shows that increasing intermediate goods trade results in a larger response of $Q$ to the shock to country A's productivity, $Z^{A}$. The movements of the relative prices of final and intermediate goods are shown in Figs. 11 and 12, respectively. As with the $D^{A}$ shock, the size of the movement in relative final goods prices decreases as intermediate goods trade rises, but the effect of this is offset by the effect of a larger coefficient on the relative intermediate goods price term, which decreases. Although the intuition is similar, the directions of movements in response to the $Z^{A}$ shock are the opposite of the $D^{A}$ shock as the latter is similar to a negative productivity shock.

As discussed above, only a modest amount of empirical evidence is available as a basis for some of the parameter choices, including $\mu$ and $\psi$, the elasticities of substitution between intermediate goods and factors of production and between domestic and imported intermediate goods, respectively. Moreover, it is reasonable to believe these elasticities might be fairly low at higher frequencies because the production structure is less flexible in the short-run. Therefore an alternative parameterization with $\mu=\psi=0.25$ is considered.

Table 8 reports results generated under this low-elasticity parameterization. These results suggest that the effects of intermediate goods trade are amplified by rigidity in the production structure. The effects of reducing $\omega$ are in the same direction as the initial parameterization, but the magnitudes of the resulting 
changes are greater. The standard deviation of the real exchange rate relative to output rises from 0.94 times with $\omega=0.95$ to 1.69 times with $\omega=0.5$ and 1.97 times with $\omega=0.95$ The increase in international output correlation is also greater with the reduced elasticities. The lower elasticities lead to greater reductions in the correlations between output and the trade balance and the negative correlation between the real exchange rate and output. This is also the case with national productivity shocks and no demand shocks, reported in Table 9 .

\section{Conclusion}

This paper demonstrates that intermediate goods trade can help account for two important aspects of exchange rate disconnect: the volatility of real exchange rates relative to output and lack of correlation between the real exchange rate and output. Intermediate goods trade also helps endogenously generate greater international output correlations and reduces the correlation between the trade balance and output. These results are stronger if the production structure is less flexible.

Although the introduction of intermediate goods moves the model closer to the data, this model does not match all aspects of the relationship between the real exchange rate, output and trade. It provides only a partial explanation of the high volatility of the real exchange rate relative to output. The mechanism in this paper is based entirely on a real aspect of economic structure and it does not include any nominal rigidities and it assumes complete international risk-sharing. The mechanisms demonstrated in this paper may be useful in combinations with others to create models which can provide a more complete explanation of the exchange disconnect puzzle. 


\section{References}

Adjemian, S., H. Bastani, M. Juillard, F. Mihoubi, G. Perendia, M. Ratto and S. Villemot, 2011. Dynare: Reference Manual, Version 4. Dynare Working Papers 1. CEPREMAP.

Ambler, S., E. Cardia and C. Zimmermann, 2002. International Transmission of the Business Cycle in a Multi-Sector Model. European Economic Review 46: 273-300.

Arkolakis, C., and A. Ramanarayanan, 2009. Vertical Specialization and International Business Cycle Synchronization. Scandinavian Journal of Economics 111(4): 655-680.

Atalay, E., 2017. How Important Are Sectoral Shocks? American Economic Journal: Macroeconomics 9(4): 254-280.

Backus, D.K., Kehoe, P.J., and F.E. Kydland, 1992. International Real Business Cycles. Journal of Political Economy 100: 745-775.

Backus, D.K., Kehoe, P.J., and F.E. Kydland, 1994. Dynamics of the Trade Balance and the Terms of Trade: The J-Curve?. American Economic Review 84(1): 84-103.

Boileau, M., 2002. Trade in Capital Goods and Investment-Specific Technical Change. Journal of Economic Dynamics \& Control 26: 963-984.

Burstein, A.T., Neves, J.C., Rebelo, S., 2003. Distribution Costs and Real Exchange Rate Dynamics During Exchange Rate-Based Stabilizations. Journal of Monetary Economics 50, 1189-1214.

Burstein, A., C. Kurz and L. Tesar, 2008. Trade, Production Sharing and the International Transmission of Business Cycles. Journal of Monetary Economics 55: 775-795.

Canova, F. and H. Dellas, 1993. Trade Interdependence and the International Business Cycle. Journal of International Economics 34: 23-47.

Corsetti, G., Dedola, L., S. Leduc, 2008. International Risk Sharing and the Transmission of Productivity Shocks. Review of Economic Studies 75: 443-473.

Craighead, W.D., 2008. Real Rigidities and Real Exchange Rate Volatility. Journal of International Money and Finance 28(1): 135-147.

Daudin, G., C. Rifflart and D. Schweisguth, 2011. Who Produces for Whom in the World Economy? Canadian Journal of Economics 44(4): 1403-1437. 
Devereux, M.B., Engel, C. Exchange Rate Pass-Through, Exchange Rate Volatility and Exchange Rate Disconnect. Journal of Monetary Economics 49(5): 913940.

Garín, J., Lester, R. and E. Sims, 2016. On the Desirability of Nominal GDP Targeting. Journal of Economic Dynamics and Control 69: 21-44.

Huang, K.X.D., and Z. Liu, 2007. Business Cycles With Staggered Prices and International Trade in Intermediate Inputs. Journal of Monetary Economics 54: 2007

Hummels, K. J. Ishii and K. Yi, 2001. The Nature and Growth of Vertical Specialization in World Trade. Journal of International Economics 54(1): 75-96.

Johnson, R., 2014. Five Facts about Value-Added Exports and Implications for Macroeconomics and Trade Research. Journal of Economic Perspectives 28(2): 119-142.

Johnson, R and G. Noguera, 2012. Accounting for Intermediates: Production Sharing and Trade in Value Added. Journal of International Economics 86: 224-236.

Johnson, R and G. Noguera, 2016. A Portrait of Trade in Value Added over Four Decades. Review of Economics and Statistics, forthcoming.

Koopman, R., Z. Wang and S. Wei, 2014. Tracing Value-Added and Double Counting in Gross Exports. American Economic Review 104(2): 459-494

Kose, A. and K. Yi, 2001. International Trade and Business Cycles: Is Vertical Specialization the Missing Link? American Economic Review 91(2): 371-375.

Lombardo, G. and F. Ravenna, 2014. Openness and Optimal Monetary Policy. Journal of International Economics 93: 153-172.

Los, B., M. Timmer and G. de Vries, 2015. How Global are Global Value Chains? A New Approach to Measure International Fragmentation. Journal of Regional Science 55(1): 66-92.

Oberfield, E. and D. Raval, 2014. Micro Data and Macro Technology. NBER Working Paper 20452.

Obstfeld, M. and K. Rogoff, 2001. The Six Major Puzzles in International Macroeconomics: Is There a Common Cause? in: B. Bernanke and K. Rogoff, eds., 2001, NBER Macroeconomics Annual 2000. Cambridge MA: MIT Press, 
pp. 339-412.

Peterman, W.B., 2016. Reconciling Micro and Macro Estimates of the Frisch Labor Supply Elasticity. Economic Inquiry 54(1): 100-120.

Rotemberg, J.J. and M. Woodford, 1996. Imperfect Competition and the Effects of Energy Price Increases on Economic Activity. Journal of Money, Credit and Banking 28(1): 549-577.

Yilmazkuday, H., 2017. Unifying Macro Elasticities in International Economics. Federal Reserve Bank of Dallas Globalization and Monetary Policy Institute Working Paper 299. 
Table 1. Standard Deviations

$\begin{array}{lcccccccc} & \text { Canada } & \text { France } & \text { Germany } & \text { Italy } & \text { Japan } & \text { UK } & \text { US } & \text { Euro Area } \\ \text { REER } & 9.77 & 19.03 & 5.28 & 3.90 & 19.84 & 12.04 & 11.03 & 9.98 \\ \text { RER vs US } & 12.12 & 18.94 & 17.90 & 16.98 & 19.64 & 19.19 & - & 16.88 \\ \text { NX/GDP } & 3.01 & 1.61 & 2.64 & 1.85 & 1.78 & 2.51 & 1.16 & 1.29 \\ \text { GDP } & 2.94 & 1.96 & 3.40 & 2.96 & 4.32 & 2.62 & 2.80 & 2.45\end{array}$

Table 2. Correlations with GDP

$\begin{array}{lcccccccc} & \text { Canada } & \text { France } & \text { Germany } & \text { Italy } & \text { Japan } & \text { UK } & \text { US } & \text { Euro Area } \\ \text { REER } & 0.01 & -0.10 & -0.15 & -0.11 & -0.25 & 0.03 & -0.15 & -0.12 \\ \text { RER vs US } & 0.11 & 0.06 & 0.07 & 0.06 & -0.13 & 0.09 & - & 0.07\end{array}$

\begin{tabular}{lcccccccc}
\multicolumn{1}{c}{} & \multicolumn{2}{c}{ Table 3. Correlations with $\frac{\mathrm{NX}}{\mathrm{GDP}}$} & & & \\
\cline { 2 - 9 } & Canada & France & Germany & Italy & Japan & UK & US & Euro Area \\
REER & 0.02 & 0.02 & 0.18 & 0.21 & -0.13 & 0.12 & 0.13 & 0.14 \\
RER vs US & 0.12 & -0.05 & 0.23 & 0.08 & -0.07 & 0.08 & - & 0.14 \\
GDP & -0.21 & 0.16 & 0.24 & -0.14 & -0.08 & 0.25 & -0.18 & -0.07
\end{tabular}

Table 4. Correlations of GDP Growth

$\begin{array}{lcccccc} & \text { France } & \text { Germany } & \text { Italy } & \text { Japan } & \text { UK } & \text { US } \\ \text { Canada } & 0.37 & 0.51 & 0.56 & 0.31 & 0.42 & 0.61 \\ \text { France } & & 0.66 & 0.81 & 0.36 & 0.50 & 0.39 \\ \text { Germany } & & & 0.69 & 0.46 & 0.52 & 0.39 \\ \text { Italy } & & & & 0.48 & 0.69 & 0.46 \\ \text { Japan } & & & & & 0.48 & 0.29 \\ \text { UK } & & & & & & 0.47\end{array}$


Table 5. Parameters

\begin{tabular}{ccl} 
Parameter & Value & Description \\
\hline$\beta$ & 0.99 & Discount factor \\
$\gamma$ & 2 & Risk aversion \\
$\theta$ & 0.5 & Inverse Frisch elasticity \\
$\alpha$ & 0.33 & Capital share \\
$\delta$ & 0.025 & Depreciation \\
$\nu$ & 0.1 & Capital adjustment cost \\
$\rho_{Z}$ & 0.9 & Productivity shock autocorrelation \\
$\rho_{D}$ & 0.7 & Preference shock autocorrelation \\
$\sigma_{Z, \varepsilon}$ & 0.01 & Std. dev. of productivity shocks \\
$\sigma_{D, \varepsilon}$ & 0.01 & Std. dev. of preference shocks \\
$\phi$ & 0.5 & Weight on home goods in consumption and investment \\
$\sigma$ & 0.45 & Weight on factor inputs in final goods production \\
$\eta$ & 1.5 & Elasticity between domestic and imported consumption \\
$\mu$ & 0.65 & Elasticity between intermediate goods and factors \\
$\psi$ & 0.75 & Elasticity between domestic and imported intermediates
\end{tabular}

Table 6. Model-Generated Results

\begin{tabular}{lccc} 
& & $\omega$ \\
& 0.95 & 0.5 & 0.05 \\
\hline Std. dev. of Y & 2.33 & 2.11 & 2.02 \\
Std. dev. of Q & 2.12 & 2.63 & 2.87 \\
Corr. $Y^{A}, Y^{B}$ & 0.17 & 0.43 & 0.55 \\
Corr. $\frac{N X^{A}}{Y^{A}}, Y^{A}$ & 0.61 & 0.51 & 0.44 \\
Corr. Q, $Y^{A}$ & -0.64 & -0.53 & -0.47
\end{tabular}

Table 7. Model-Generated Results (National Productivity Shocks)

\begin{tabular}{lccc} 
& & $\omega$ \\
& 0.95 & 0.5 & 0.05 \\
\hline Std. dev. of Y & 3.07 & 2.77 & 2.65 \\
Std. dev. of Q & 2.80 & 3.42 & 3.75 \\
Corr. $Y^{A}, Y^{B}$ & 0.16 & 0.42 & 0.56 \\
Corr. $\frac{N X}{Y}, Y$ & 0.62 & 0.53 & 0.45 \\
Corr. Q, $Y^{A}$ & -0.65 & -0.55 & -0.47
\end{tabular}


Table 8. Model-Generated Results (Low Elasticity)

\begin{tabular}{lccc}
\hline & & $\omega$ & \\
& 0.95 & 0.5 & 0.05 \\
\hline Std. dev. of $\mathrm{Y}$ & 2.31 & 1.94 & 1.84 \\
Std. dev. of $\mathrm{Q}$ & 2.16 & 3.27 & 3.63 \\
Corr. $Y^{A}, Y^{B}$ & 0.19 & 0.69 & 0.87 \\
Corr. $\frac{N X^{A}}{Y^{A}}, Y^{A}$ & 0.60 & 0.32 & 0.21 \\
Corr. Q, $Y^{A}$ & -0.64 & -0.35 & -0.25
\end{tabular}

Table 9. Model-Generated Results (Low Elasticity, National Productivity Shocks)

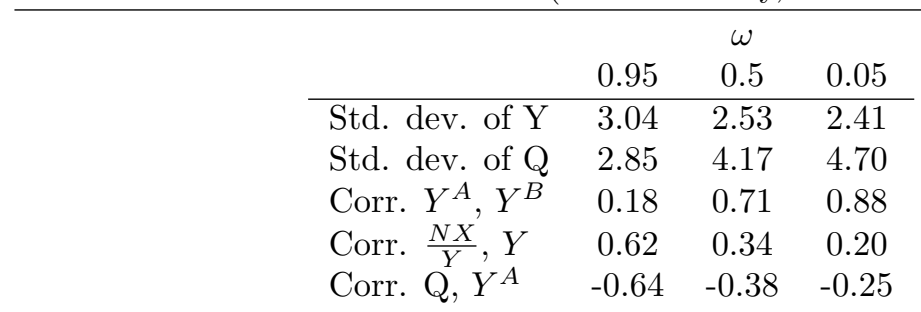


Fig. 1: Response of $\widehat{Q}$ to $\widehat{Z}^{F, A}$ shock

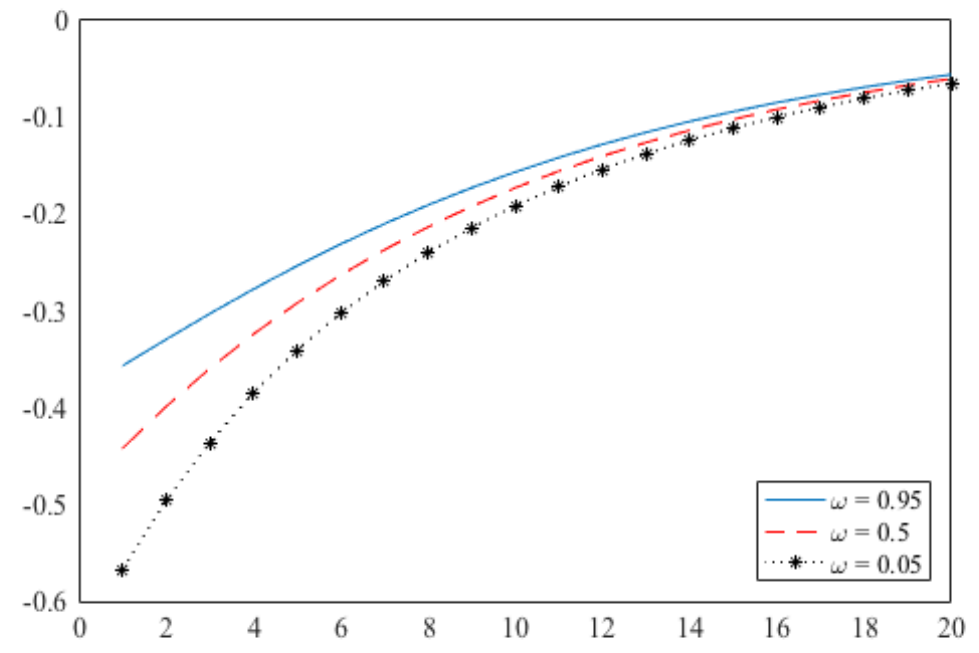

Fig. 2: Response of $\widehat{Q}$ to $\widehat{Z}^{M, A}$ shock

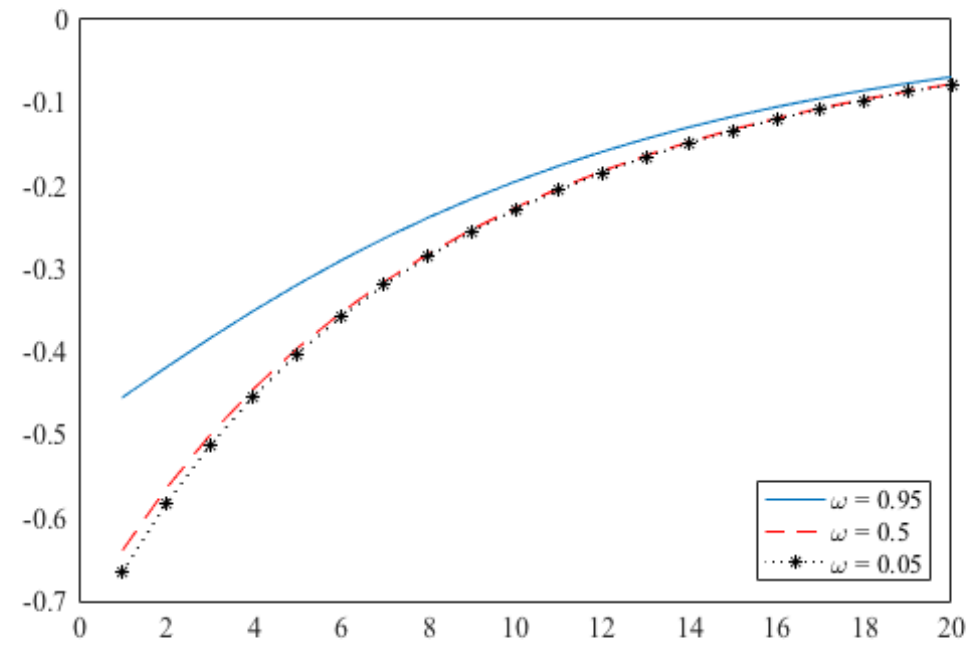


Fig. 3: Response of $\widehat{P}^{F, A}-\widehat{P}^{F, B}$ to $\widehat{Z}^{F, A}$ shock

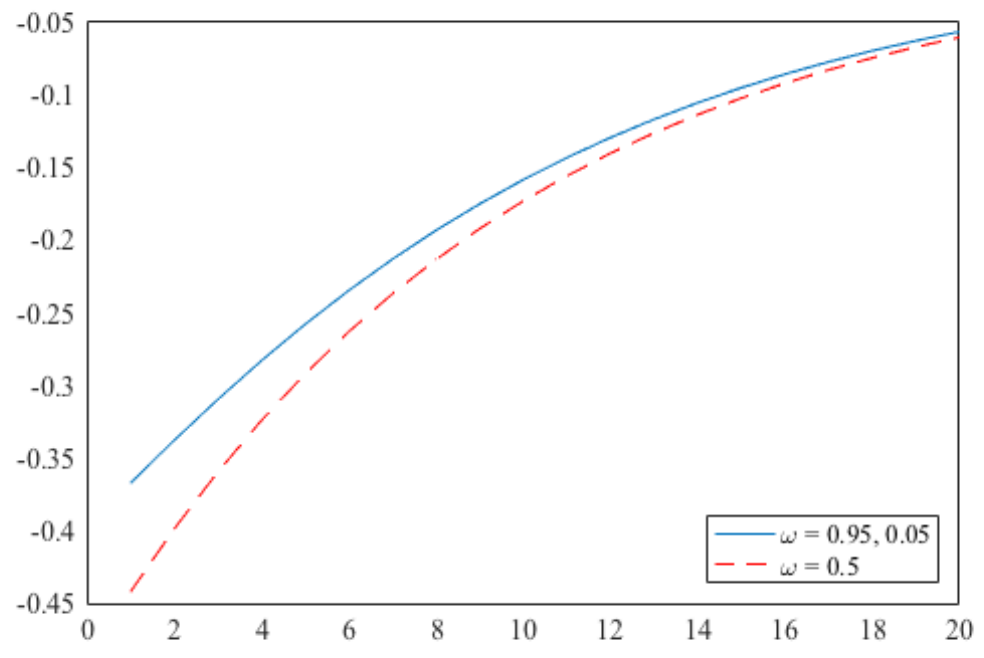

Fig. 4: Response of $\widehat{P}^{M, A}-\widehat{P}^{M, B}$ to $\widehat{Z}^{F, A}$ shock

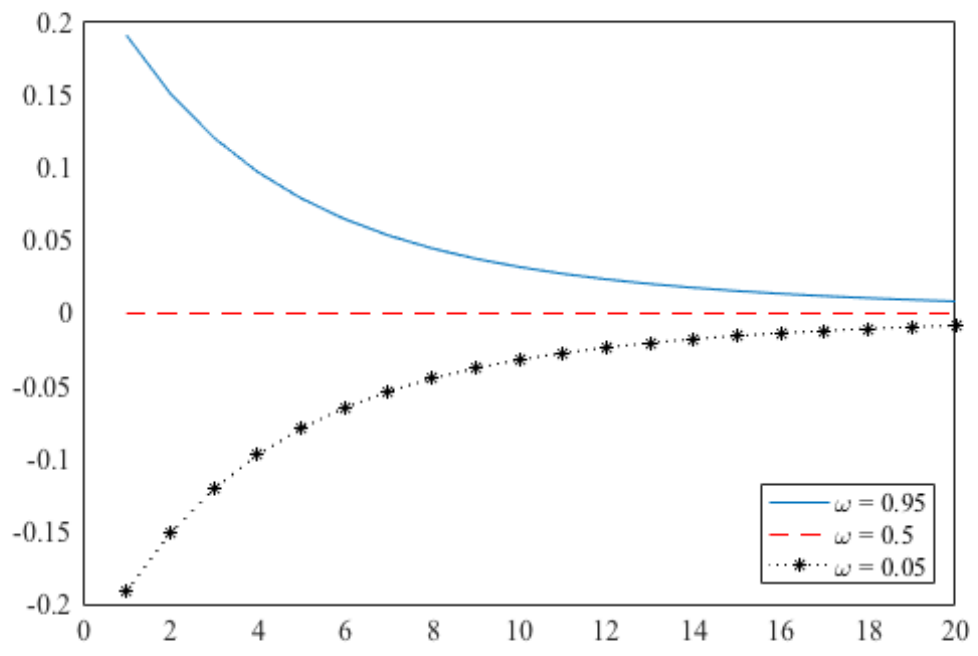


Fig. 5: Response of $\widehat{P}^{M, A}-\widehat{P}^{M, B}$ to $\widehat{Z}^{M, A}$ shock

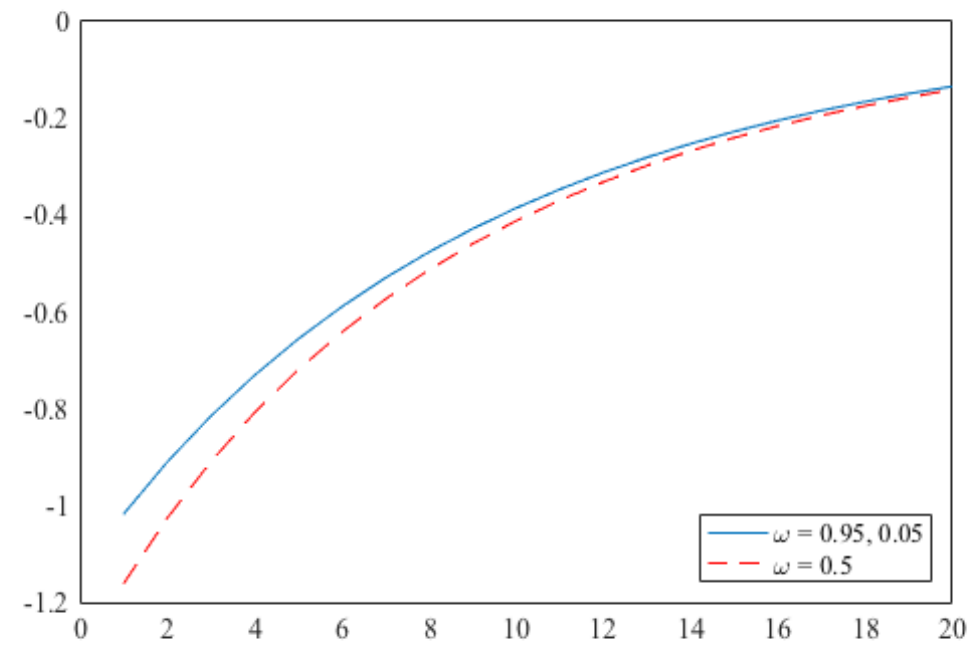

Fig. 6: Response of $\widehat{P}^{F, A}-\widehat{P}^{F, B}$ to $\widehat{Z}^{M, A}$ shock

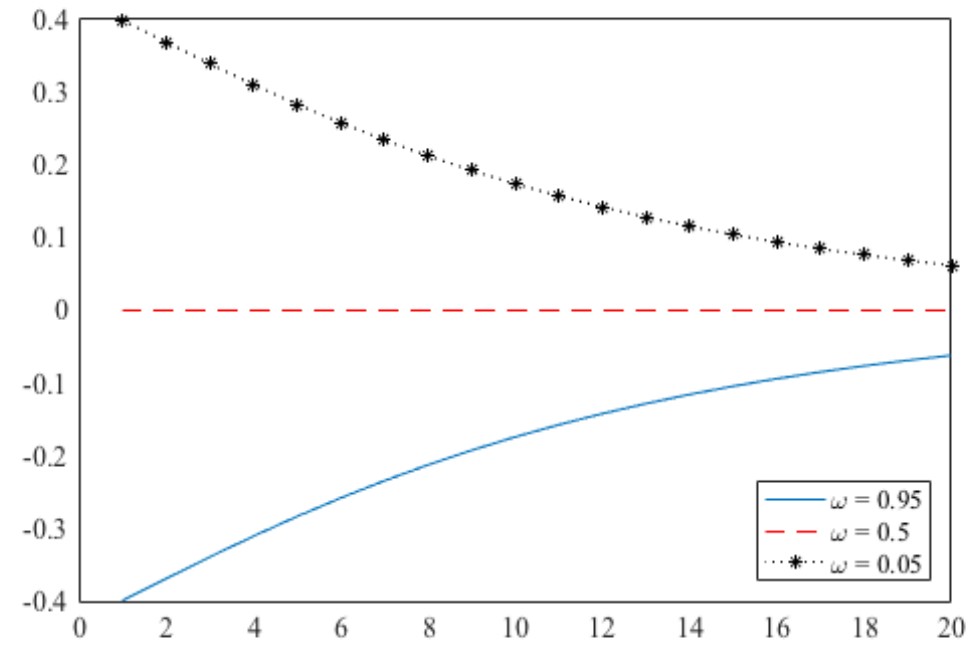


Fig. 7: Response of $\widehat{Q}$ to $\widehat{D}^{A}$ shock

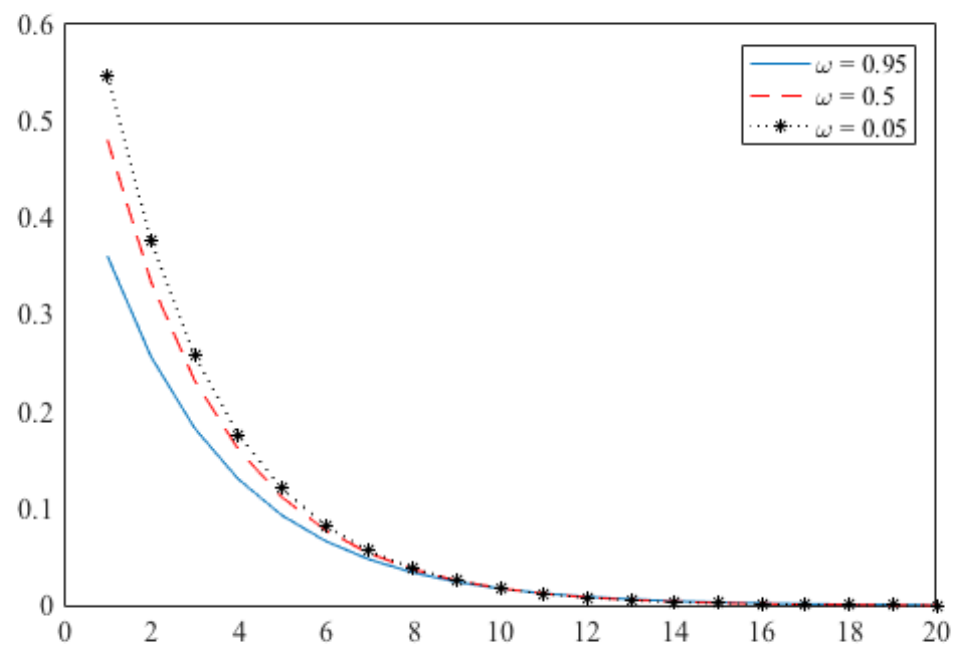

Fig. 8: Response of $\widehat{P}^{F, A}-\widehat{P}^{F, B}$ to $\widehat{D}^{A}$ shock

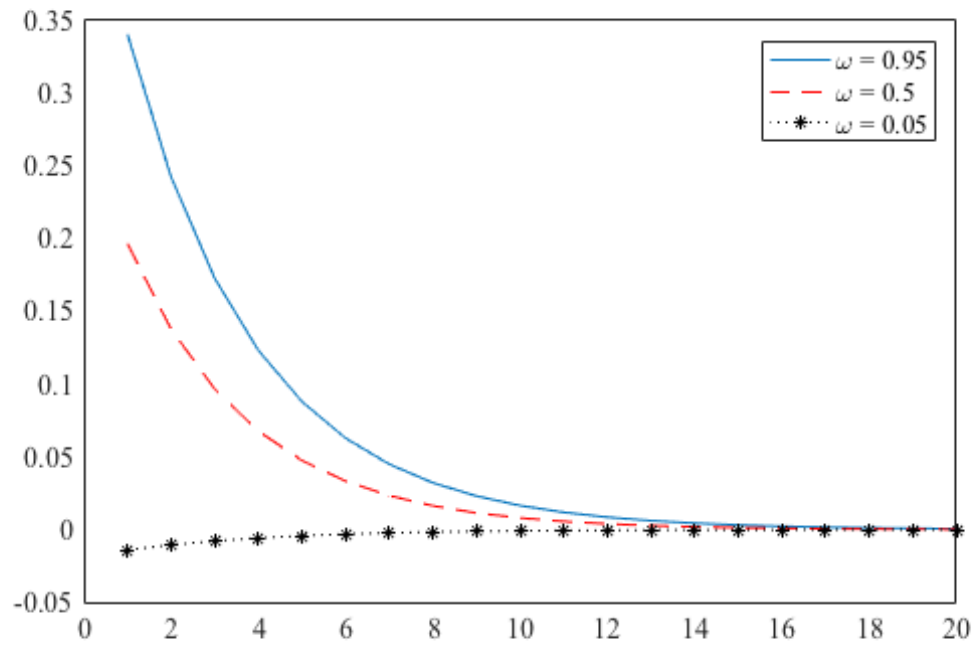


Fig. 9: Response of $\widehat{P}^{M, A}-\widehat{P}^{M, B}$ to $\widehat{D}^{A}$ shock

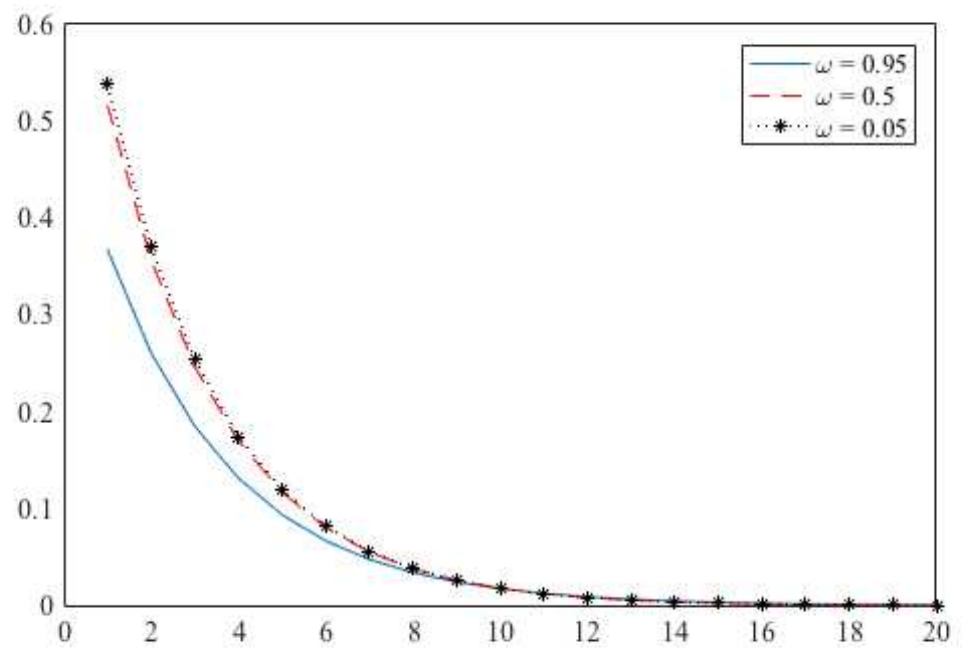

Fig. 10: Response of $\widehat{Q}$ to $\widehat{Z}^{A}$ shock

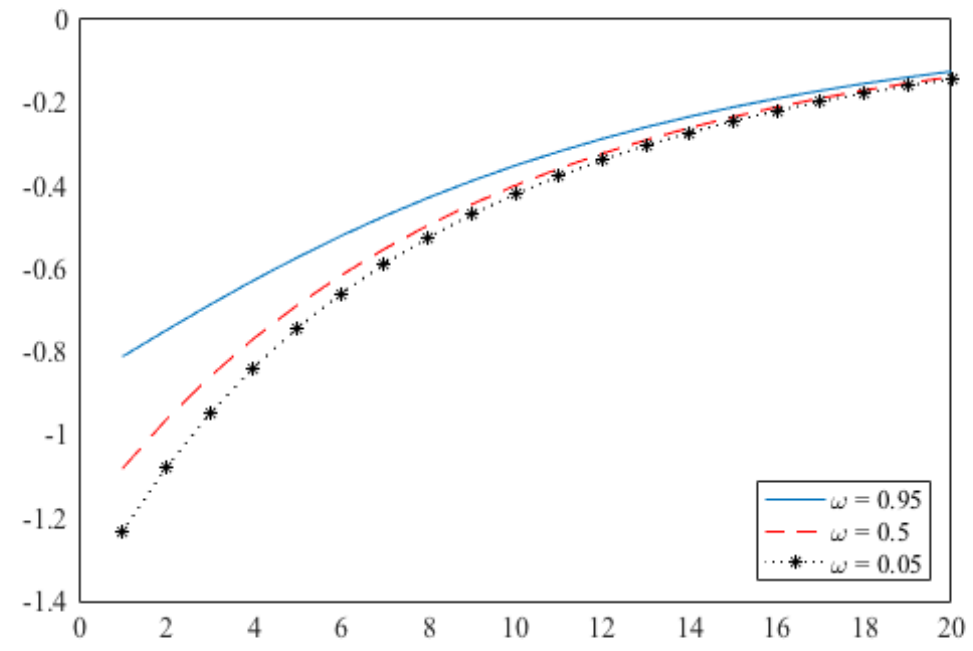


Fig. 11: Response of $\widehat{P}^{F, A}-\widehat{P}^{F, B}$ to $\widehat{Z}^{A}$ shock

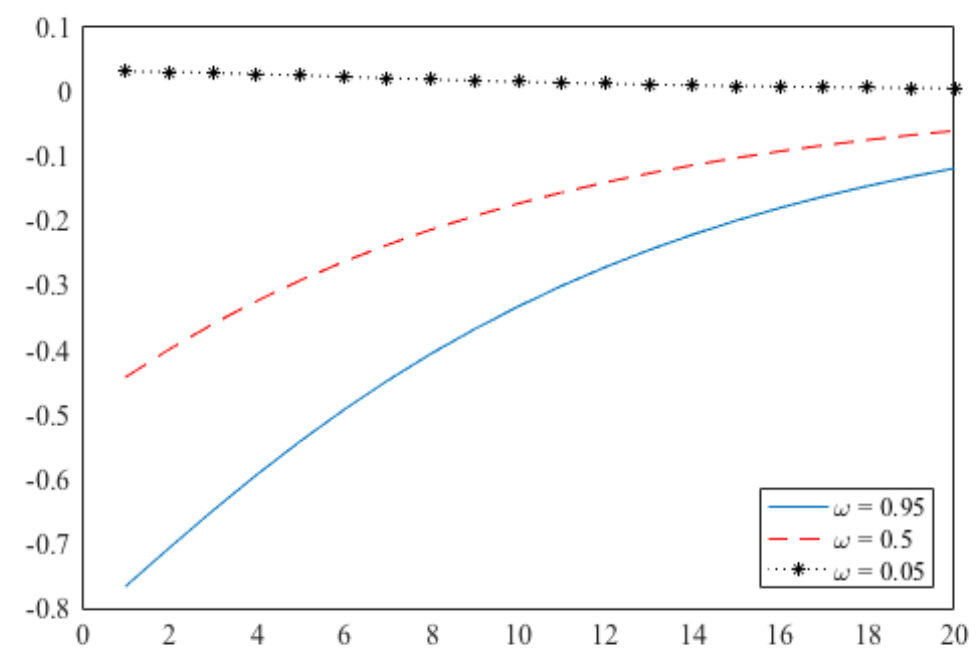

Fig. 12: Response of $\widehat{P}^{M, A}-\widehat{P}^{M, B}$ to $\widehat{Z}^{A}$ shock

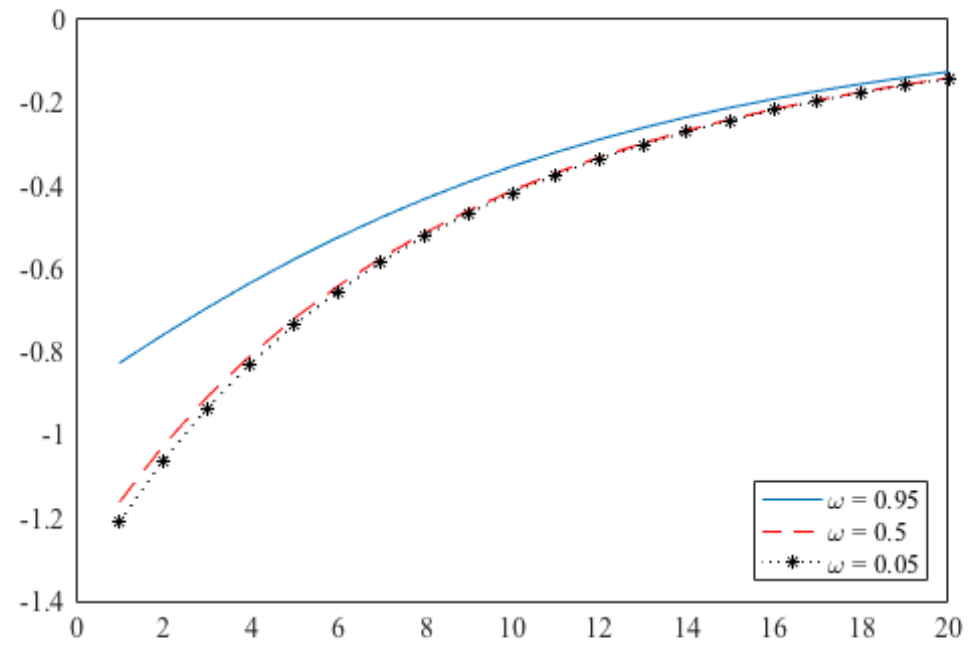

